\title{
Effect of Alum-treated Groundnut (Arachis hypogea) Shell Meal on Blood Chemistry and Carcass Characteristics of Broiler Chickens
}

\author{
EGBEWANDE, OO
}

Department of Animal Production, Faculty of Agriculture, Ibrahim Badamasi Babangida University, P.M.B. 11, Lapai, Niger State, Nigeria *Corresponding Author Email: femi2015.ooe@gmail.com; Tel: +2347068233925

\begin{abstract}
Effect of alum-treated groundnut (Arachis hypogea) shell (ATGNS) meal was studied on the blood chemistry and carcass characteristics of broiler chickens. Two hundred and forty (240) day-old broiler chicks of Anak strain were used for the study in a completely randomized design for eight weeks. The chicks were allotted into six groups of forty chicks each and further divided into four replicates of ten chicks each.Groundnut shell (GNS) was processed by soaking it in water containing alum in ratio $1 \mathrm{~kg}$ of groundnut shell: 15 litre of water: $600 \mathrm{~g}$ of alum for three, four, five and six days. Wheat offal was included at $10 \%$ in $\mathrm{T} 1$ as positive control, $4 \%$ wheat offal and $6 \%$ untreated groundnut shell (GNS) in T2 as negative control, and 4\% wheat offal with $6 \%$ treated GNS in treatments 3, 4, 5 and 6 at three days, four day, five days and six days of processing respectively. Results on haematological parameters were not significantly $(\mathrm{p}>0.05)$ different except mean corpuscular volume (MCV) and mean corpuscular haemoglobin $(\mathrm{MCH})$. Birds in T5 performed better than others in mean corpuscular volume (MCV) and mean corpuscular haemoglobin (MCH) with highest values of $123.83 \%$ and $41.93 \mathrm{pg}$ respectively, while birds in T3 had the lowest values of $115.28 \%$ and $39.05 \mathrm{pg}$ in the two parameters respectively. There were significant $(\mathrm{p}<0.05)$ differences in serum total protein, albumin and globulin, while other parameters measured showed no significant $(\mathrm{p}>0.05)$ differences in serum biochemical studies. Birds fed treatment 1 (T1) had the highest values of 3.95 and $2.72 \mathrm{~g} / \mathrm{dl}$ in total protein and globulin respectively, while the lowest values 2.55 and $0.97 \mathrm{~g} / \mathrm{dl}$ were obtained from birds in T6 respectively. Cut-up parts showed significant $(\mathrm{p}<0.05)$ differences in head, neck, back and thigh across treatment means with the exception of other parameters considered. The live weights of birds on processed groundnut shell meal, although not significantly $(\mathrm{p}>0.05)$ different, were better $(\mathrm{p}<0.05)$ than those on untreated groundnut shell meal (T2). Birds in T6 had the highest values (2.95, 4.60 and 12.53\%) in head, neck and thigh respectively. The highest weight (18.02\%) of back was recorded in T1. Birds in T4 had the highest values of 19.60 and $4.20 \%$ in breast muscle and shank respectively, while those in T3 recorded the lowest (14.65\%) in breast muscle, and those in T2 had the lowest (3.56\%) in shank. The results in conclusion, showed that alum-treated groundnut shell (ATGNS) could replace wheat offal at $6 \%$ level of inclusion by improving carcass yield as well as maintainingblood profile of broiler chickens.
\end{abstract}

\section{DOI:https://dx.doi.org/10.4314/jasem.v24i9.12}

Copyright: Copyright $($ C 2020 Egbewande. This is an open access article distributed under the Creative Commons Attribution License (CCL), which permits unrestricted use, distribution, and reproduction in any medium, provided the original work is properly cited.

Dates: Received: 10 August 2020; Revised: 16 September 2020; Accepted: 22 September 2020

Keywords: Groundnut shell, alum, blood chemistry, carcass, broiler

It is a fact that exorbitant prices of feed ingredients/feedstuffs had led to high cost of compounded feed for poultry. This resulted to increasing competitive demand for ingredients of protein and energy sources by both human and livestock which also led to scarcity of conventional ingredients. Therefore, efforts should be geared towards reducing the cost of feeds, which according to Nworgu et al. (1999), is about $70 \%$ of the whole cost of production. Researchers have made concerted efforts toward evaluating alternative feed ingredients for poultry (Ojewola et al, 2003). In line with this, such alternatives should be cheaper than the conventional ingredient sources, have comparative nutritive value, and be available in large quantities. The search for cheaper feed components is currently exploring the replacement of those conventional feedstuffs with cheaper alternatives in the formulation of poultry feed. Some agricultural by-products like groundnut shell requires some processing. Many researchers have worked on the use of chemicals, fermentation, soaking and treatment with some diluents. Groundnut shell which is abandoned after harvesting, are seen littering the environment and little or no care is been attached to it in turning the waste to wealth. Nigeria is the third leading producer of groundnut in the world producing 1.92 million tons of it and after processing groundnut realizing about 0.288 million tons of groundnut shell as a by-product, FAOSTAT (1999), but this by-product is poorly utilized. Groundnut shell is a valuable feed resource that can be useful for feeding livestock after further processing. According to Siulapwa and Simukoko (2005), the crude protein, crude fibre, calcium and phosphorous in groundnut pod are 10.4, 31.2, 0.93 and $0.87 \%$ respectively. Muftau et al. (2014) reported that 
treated groundnut shell is a possible feed resource for broiler chickens to replace wheat offal meal above $30 \%$ inclusion for effective growth performance at reduced cost of production. However, the lignin found in the groundnut shell limits the utilization by either ruminant or monogastric animals. Thus, the breaking of this lignin is very important by subjecting it to serious processing. The present study therefore investigated the effects of dietary inclusion of alumtreated groundnut shell on blood chemistry and carcass characteristics of broiler chickens.

\section{MATERIALS AND METHODS}

Study Area: The experiment was carried out at the poultry unit of Teaching and Research Farm, Ibrahim Badamasi Babangida University, Lapai, Niger State. Lapai is very close to Minna which is the capital and lies between Latitude $9.02^{\circ} \mathrm{N}$ and Longitude $6.34^{\circ} \mathrm{E}$ of the equator (Usman, 2013). The area falls within the Southern Guinea Savannah Vegetation Zone of Nigeria with mean annual rainfall ranging between 1100-1600mm (Usman 2013).
Source and Processing of Test Ingredient: The groundnut (Arachis hypogea) shell was obtained within Lapai community and treated by soaking it in water that contained alum in ratio; $1 \mathrm{~kg}$ of groundnut shell (GNS): 15litre of Water: $600 \mathrm{~g}$ of alum. The number of days for the soaking varied in accordance with the treatments. Treatment 1 (T1) did not have GNS and served as positive control. In T2, untreated GNS was included (Negative control). T3 contained GNS that was soaked for three days, T4 contained GNS soaked for four days, T5 contained GNS soaked for five days and T6 contained GNS soaked for six days.

Experimental Diets: Six (6) diets were compounded using groundnut shell to replace wheat offal both in starter and finisher diets. Wheat offal was included at $10 \%$ in $\mathrm{T} 1$ as control, $4 \%$ wheat offal and $6 \%$ untreated GNS in T2, and 4\% wheat offal with $6 \%$ treated GNS in treatments 3, 4, 5 and 6 at three days, four day, five days and six days respectively. The diets were compounded to contain $22.19 \%$ and $2797.98 \mathrm{kcal} / \mathrm{kg}$, and $19.70 \%$ and $2782.46 \mathrm{kcal} / \mathrm{kg}$, crude protein and metabolizable energy for both starter and finisher diets respectively.

Table 1: Gross composition of experimental broiler starter diets

\begin{tabular}{lllllll}
\hline Ingredients (\%) & T1 & T2 & T3 & T4 & T5 & T6 \\
\hline Maize & 50.06 & 50.06 & 50.06 & 50.06 & 50.06 & 50.06 \\
Groundnut cake & 10.88 & 10.88 & 10.88 & 10.88 & 10.88 & 10.88 \\
Soyabean meal & 20.21 & 20.21 & 20.21 & 20.21 & 20.21 & 20.21 \\
Wheat offal & 10.00 & 04.00 & 04.00 & 04.00 & 04.00 & 04.00 \\
Groundnut shell & - & 06.00 & 06.00 & 06.00 & 06.00 & 06.00 \\
Fish meal & 04.00 & 04.00 & 04.00 & 04.00 & 04.00 & 04.00 \\
Bone meal & 02.20 & 02.20 & 02.20 & 02.20 & 02.20 & 02.20 \\
Limestone & 00.80 & 00.80 & 00.80 & 00.80 & 00.80 & 00.80 \\
*Premix & 00.25 & 00.25 & 00.25 & 00.25 & 00.25 & 00.25 \\
Salt & 00.30 & 00.30 & 00.30 & 00.30 & 00.30 & 00.30 \\
Lysine & 00.20 & 00.20 & 00.20 & 00.20 & 00.20 & 00.20 \\
Methionine & 00.20 & 00.20 & 00.20 & 00.20 & 00.20 & 00.20 \\
Total & 100.00 & 100.00 & 100.00 & 100.00 & 100.00 & 100.00 \\
Calculated (\%) & & & & & & \\
Crude protein & 22.19 & 22.07 & 22.07 & 22.07 & 22.07 & 22.07 \\
Crude fibre & 4.33 & 3.99 & 3.99 & 3.99 & 3.99 & 3.99 \\
Ether extract & 4.23 & 4.12 & 4.12 & 4.12 & 4.12 & 4.12 \\
Ash & 3.17 & 3.29 & 3.29 & 3.29 & 3.29 & 3.29 \\
Calcium & 1.38 & 1.37 & 1.37 & 1.37 & 1.37 & 1.37 \\
Phosphorus & 0.76 & 0.77 & 0.77 & 0.77 & 0.77 & 0.77 \\
ME (kcal/kg) & 2797.98 & 2877.78 & 2877.78 & 2877.78 & 2877.78 & 2877.78 \\
\hline
\end{tabular}

*Davo premix: Vitamin A (10,000,000 iu), Vitamin D3 (2,000,000), Vitamin E (20,000mg),Vitamin K3 (2,000mg), Vitamin B1 (3,000mg), Vitamin B2 (5,000mg), Niacin (45,000mg), Calcium pantothenate (10,000mg), Vitamin B6 (4,000mg), Vitamin B12 (20mg), Choline chloride (300,000mg), Folic acid (1,000mg), Biotin (50mg), Manganese (300,000mg), Iron (120,000mg), Zinc (80,000mg), Copper (8,500mg), Iodine (1,500mg), Cobalt (300mg), Selenium (120mg), Antioxidant (120,000mg).

Experimental Birds and Management: Two hundred and forty (240) day-old broiler chicks were purchased from a reputable farm and used for the experiment. The birds were allotted into six (6) dietary treatments with four (4) replicates each in a completely randomized design (CRD). The birds were weighed on arrival to get the initial weight of the chicks. Anti- stress (Vitalyte) was administered in water and served to the chicks. When the chicks were 10 days old, Lasota ( $1^{\text {st }}$ dose $)$ vaccine against NCD was administered and at week three Gumboro vaccine against IBD was administered. At week five the second dose of Lasota vaccine was administered. The experiment lasted for eight (8) weeks.. 
Table 2: Gross composition of experimental broiler finisher diets

\begin{tabular}{lllllll}
\hline Ingredients (\%) & T1 & T2 & T3 & T4 & T5 & T6 \\
\hline Maize & 50.60 & 50.60 & 50.60 & 50.60 & 50.60 & 50.60 \\
Soyabean meal & 31.82 & 31.82 & 31.82 & 31.82 & 31.82 & 31.82 \\
Wheat offal & 10.00 & 04.00 & 04.00 & 04.00 & 04.00 & 04.00 \\
Groundnut shell & - & 06.00 & 06.00 & 06.00 & 06.00 & 06.00 \\
Bone meal & 00.30 & 00.30 & 00.30 & 00.30 & 00.30 & 00.30 \\
Limestone & 00.05 & 00.05 & 00.05 & 00.05 & 00.05 & 00.05 \\
*Premix & 00.25 & 00.25 & 00.25 & 00.25 & 00.25 & 00.25 \\
Salt & 00.30 & 00.30 & 00.30 & 00.30 & 00.30 & 00.30 \\
Lysine & 00.20 & 00.20 & 00.20 & 00.20 & 00.20 & 00.20 \\
Methionine & 00.20 & 00.20 & 00.20 & 00.20 & 00.20 & 00.20 \\
Total & 100.00 & 100.00 & 100.00 & 100.00 & 100.00 & 100.00 \\
Calculated: & & & & & & \\
Crude protein & 19.70 & 19.58 & 19.58 & 19.58 & 19.58 & 19.58 \\
Crude fibre & 4.53 & 4.19 & 4.19 & 4.19 & 4.19 & 4.19 \\
Ether extract & 3.93 & 3.82 & 3.82 & 3.82 & 3.82 & 3.82 \\
Ash & 2.61 & 2.73 & 2.73 & 2.73 & 2.73 & 2.73 \\
Calcium & 1.31 & 1.31 & 1.31 & 1.31 & 1.31 & 1.31 \\
Phosphorus & 0.82 & 0.82 & 0.82 & 0.82 & 0.82 & 0.82 \\
ME (kcal/kg) & 2782.46 & 2862.26 & 2862.26 & 2862.26 & 2862.26 & 2862.26 \\
\hline
\end{tabular}

*Davo premix: Vitamin A (10,000,000 iu), Vitamin D3 (2,000,000), Vitamin E (20,000mg), Vitamin K3 (2,000mg), Vitamin B1 (3,000mg), Vitamin B2 (5,000mg), Niacin (45,000mg), Calcium pantothenate (10,000mg), Vitamin B6 (4,000mg), Vitamin B12 (20mg), Choline chloride (300,000mg), Folic acid (1,000mg), Biotin (50mg), Manganese (300,000mg), Iron (120,000mg), Zinc (80,000mg), Copper (8,500mg), Iodine (1,500mg), Cobalt (300mg), Selenium (120mg), Antioxidant (120,000mg).

Data Collection: Data were collected on blood chemistry (haematological and serum parameters), and carcass characteristics

Blood Chemistry: At the end of the experiment (8 weeks) two birds per replicate were randomly selected and off feed overnight. They were weighed and bled via jugular vein for blood collection. A $2 \mathrm{ml}$ of blood was collected into plane bottles for serum biochemical tests, while $1 \mathrm{ml}$ of blood into bottles containing $2 \mathrm{mg}$ of ethylene diamine tetra-acetic acid (EDTA) to determine hematological parameters. The blood sample for serum was allowed to clot and used to determine serum parameters: total protein (TP), albumin, globulin, cholesterol, and alkaline phosphatase (ALP). The serum was separated immediately after clotting by centrifugation at 2000 revolutions per minute for 10 minutes. The biuret method was used in the determination of the total protein fraction, and the serum albumin following the procedures of Peters et al. (1982). Globulin was determined according to the method of Kohn and Allen (1995), while the serum enzymes were obtained calorimetrically using the Randox Laboratory Ltd. Co. Antrim, UK test kits.

In haematological analysis, red blood cell and white blood counts were determined by haemocytometer method using Natt-Herrick solution. Packed cell volume was measured by micro-haematocrit method while haemoglobin values were measured by Sahli's method (Konuk, 1981). Neutrophils, lymphocytes and monocytes were determined using procedures described by Ewuola and Egbunike (2008), while
$\mathrm{MCH}, \mathrm{MCV}$ and $\mathrm{MCHC}$ were calculated according to the procedures of Jain (1986).

$$
\begin{aligned}
(\mathrm{MCH}) & =\frac{\mathrm{Hb} \times 10}{\mathrm{RBC}} \\
(\mathrm{MCV}) & =\frac{\mathrm{PCV} \times 10}{\mathrm{RBC}} \\
(\mathrm{MCHC}) & =\frac{\mathrm{Hb} \times 100}{\mathrm{PCV}}
\end{aligned}
$$

Where $\mathrm{MCH}=$ Mean Corpuscular Haemoglobin; $\mathrm{MCV}=$ Mean Corpuscular Volume; $\mathrm{MCHC}=$ Mean Corpuscular Haemoglobin Concentration

Carcass Characteristics: This was carried out at the end of the experiment. Two birds per replicate were randomly selected, starved of feed overnight and slaughtered by severing the jugular vein with knife. The slaughtered birds were immersed in warm water to pluck the feathers manually. Each bird was cut into parts and the visceral removed carefully. The visceral organs (Liver, spleen, kidney, heart, gizzard, abdominal fat, and pancreas) and cut up parts (breast, back, drum sticks, thighs and wings) were weighed. The visceral organs and the cut-up parts were weighed in grams, and converted to percentages live weight:

$$
\begin{gathered}
\text { Cut }- \text { up part }(\%)=\frac{W o P(g)}{L W(g)} \times 100 \\
\text { Visceral }(\%)=\frac{W o O(g)}{L W(g)} \times 100
\end{gathered}
$$


WoP $=$ Weight of Part; $\mathrm{WoO}=$ Weight of Organ; LW $=$ Liver weight

Statistical Analysis: Data were collected and subjected to Analysis of Variance (ANOVA) according to the procedure of Steel and Torrie (1980), and significant means were separated using Duncan Multiple Range Test (Duncan 1955).

\section{RESULTS AND DISCUSSION}

Haematological Parameter of Birds Fed with Test Ingredient: Results of the Haematological parameters were shown Table 3 . There were no significant $(p>0.05)$ differences in packed cell volume (PCV), haemoglobin $(\mathrm{Hb})$, red blood cell (RBC), white blood cell (WBC), neutrophils, lymphocytes, monocytes and mean corpuscular haemoglobin concentration. Birds in T2 perform better in PVC, Haemoglobin, RBC, neutrophil and Lymphocytes than other treatments, while those in T6 had the lowest in all the parameters. There were significant $(\mathrm{p}<0.05)$ differences in the mean corpuscular volume (MCV) and mean corpuscular haemoglobin (MCH) across the treatments. Birds in T5 performed better than others in mean corpuscular volume (MCV) and mean corpuscular haemoglobin $(\mathrm{MCH})$ with highest values of $123.83 \%$ and $41.93 \mathrm{pg}$ respectively, while birds in $\mathrm{T} 3 \mathrm{had}$ the lowest values of $115.28 \%$ and $39.05 \mathrm{pg}$ in the two parameters respectively. Birds in T1 recorded highest $(34.08 \%)$ mean corpuscular haemoglobin concentration (MCHC) while those in $\mathrm{T} 6$ recorded the lowest (33.20\%). Results obtained for haematological parameters showed that there were no significant ( $p>0.05$ ) differences except in MCV and MCH.This is an indication that the dietary treatment did not have negative effect on the health status of the birds. This coincided with the report of Odetola et al. (2012) that blood parameters are reflections of the effects of dietary treatments on the animals in terms of the type, quality and amount of the ingested and available for the animal to meet its physiological, biochemical and metabolic necessities. Values obtained for the two parameters $(\mathrm{MCV}$ and $\mathrm{MCH})$ were above the ranges reported by Wikivet (2013). The values obtained from this study were close to the report of Muhammad and Oloyede (2009) when broiler chickens were fed Aspergillus niger-fermented Terminalia catappa seed meal-based diet, and also close to the reports of Odetola et al. (2014) who studied the effects of raw and roasted kenaf seed meal as a replacement for full fat soybean meal on haematology, serum biochemistry and relative weight of broiler chickens.

Table 3: Haematological parameters of birds fed test ingredient

\begin{tabular}{lllllllll}
\hline Parameter & T1 & T2 & T3 & T4 & T5 & T6 & SEM & $p$ value \\
\hline Packed cell volume (\%) & 27.63 & 28.95 & 24.45 & 26.78 & 25.00 & 23.60 & 2.77 & 0.10 \\
Haemoglobin (g/dl) & 9.40 & 9.70 & 8.28 & 9.00 & 8.55 & 8.00 & 0.95 & 0.13 \\
RBC (x 10 12/l) & 2.31 & 2.43 & 2.13 & 2.22 & 2.03 & 1.99 & 0.25 & 0.14 \\
WBC & 104.80 & 97.14 & 84.48 & 95.38 & 83.50 & 76.96 & 13.19 & 0.08 \\
Neutrophils (\%) & 0.82 & 2.05 & 1.65 & 0.67 & 1.85 & 1.01 & 0.99 & 0.24 \\
Lymphocytes (\%) & 21.64 & 64.21 & 81.22 & 42.18 & 74.41 & 66.60 & 26.75 & 0.06 \\
Monocytes (\%) & 2.08 & 5.68 & 6.16 & 3.18 & 7.25 & 5.10 & 2.36 & 0.20 \\
MCV (\%) & $119.61^{\mathrm{b}}$ & $119.14^{\mathrm{b}}$ & $114.79^{\mathrm{bc}}$ & $120.63^{\mathrm{ab}}$ & $123.15^{\mathrm{a}}$ & $118.59^{\mathrm{b}}$ & 3.14 & 0.07 \\
MCH (pg) & $40.69^{\mathrm{ab}}$ & $39.92^{\mathrm{b}}$ & $38.87^{\mathrm{b}}$ & $40.54^{\mathrm{ab}}$ & $42.12^{\mathrm{a}}$ & $40.20^{\mathrm{ab}}$ & 1.03 & 0.02 \\
MCHC (\%) & 34.02 & 33.51 & 33.87 & 33.61 & 34.20 & 33.90 & 0.71 & 0.38 \\
\hline
\end{tabular}

Means with no superscripts on the same row does not differ significantly ( $p>0.05), a, b$ : means with different superscripts on the same row differ significantly ( $p<0.05)$. SEM = Standard Error of Means, RBC $=$ Red Blood Cell, WBC $=$ White Blood Cell, MCV = Mean Corpuscular Volume, $M C H=$ Mean Corpuscular Haemoglobin, MCHC = Mean Corpuscular Haemoglobin Concentration

Table 4: Serum parameters of birds fed test ingredient

\begin{tabular}{lllllllll}
\hline Parameter & $\mathrm{T} 1$ & $\mathrm{~T} 2$ & $\mathrm{~T} 3$ & $\mathrm{~T} 4$ & $\mathrm{~T} 5$ & $\mathrm{~T} 6$ & SEM & $p$ value \\
\hline Total protein $(\mathrm{g} / \mathrm{dl})$ & $3.95^{\mathrm{a}}$ & $3.25^{\mathrm{b}}$ & $3.40^{\mathrm{ab}}$ & $3.33^{\mathrm{b}}$ & $3.50^{\mathrm{ab}}$ & $2.55^{\mathrm{c}}$ & 0.50 & 0.02 \\
Albumin $(\mathrm{g} / \mathrm{dl})$ & $1.23^{\mathrm{ab}}$ & $1.55^{\mathrm{a}}$ & $1.60^{\mathrm{a}}$ & $1.35^{\mathrm{ab}}$ & $1.58^{\mathrm{a}}$ & $1.58^{\mathrm{a}}$ & 0.19 & 0.08 \\
Globulin $\mathrm{g} / \mathrm{dl})$ & $2.72^{\mathrm{a}}$ & $1.70^{\mathrm{b}}$ & $1.80^{\mathrm{b}}$ & $1.98^{\mathrm{ab}}$ & $1.92^{\mathrm{ab}}$ & $0.97^{\mathrm{bc}}$ & 0.46 & 0.05 \\
Cholesterol & 117.75 & 110.75 & 96.50 & 93.75 & 121.25 & 98.50 & 19.56 & 0.62 \\
ALP $(\mathrm{IU} / \mathrm{L})$ & 61.25 & 63.75 & 64.00 & 64.00 & 64.00 & 64.00 & 1.41 & 0.33 \\
SGOT & 10.30 & 13.23 & 8.18 & 10.38 & 10.95 & 7.93 & 3.49 & 0.64 \\
SGPT & 16.48 & 16.70 & 15.30 & 15.65 & 14.25 & 15.28 & 2.07 & 0.80 \\
\hline
\end{tabular}

Means with no superscripts on the same row does not differ significantly ( $p>0.05), a, b, c:$ means with different superscripts on the same row differ significantly $(p<0.05)$. SEM = Standard Error of Means, T1 = without GNS, T2 = untreated GNS, T3 = GNS soaked for three days, T4 $=$ GNS soaked for four days, T5 $=$ GNS soaked for five days, T6 $=$ GNS soaked for six days

Serum Biochemistry Parameters of Bird Fed with Test Ingredients: The results for serum biochemistry parameters (Total protein, Albumin, Globulin, Cholesterol, ALP, SGOT and SGPT) were shown in Table 4. Treatment diets significantly $(p>0.05)$ influenced total protein, albumin and globulin, but other parameters [(Cholesterol Alkaline phosphatase (ALP), Serum glutamate oxaloacetate transaminase (SGOT) and Serum glutamate pyruvate transaminate (SGPT)] were not influenced statistically. Birds fed 
treatment 1 (T1) had the highest values of 3.95 and $2.72 \mathrm{~g} / \mathrm{dl}$ in total protein and globulin respectively, while the lowest values 2.55 and $0.97 \mathrm{~g} / \mathrm{dl}$ were obtained from birds in T6 respectively. Birds in T5 recorded the highest (121.25) amount of cholesterol. Birds in $\mathrm{T} 3$ recorded the highest $(1.60 \mathrm{~g} / \mathrm{dl})$ in albumin, while those fed control (T1) had the lowest (1.23g/dl). Total protein values obtained in this study were higher than the range $(0.55-1.09 \mathrm{~g} / \mathrm{l})$ reported by Muftau et al. (2015) who replaced wheat offal with fermented groundnut husk in broiler diets, but lower than the report of Wikivet (2013). Albumin values across the treatments were lower than the report of Tijani et al. (2015) who examined the haematological and serum biochemical profiles of broiler chickens fed diets of moringa leaf meal.

Carcass Characteristics of Broiler Chickens Fed Test Ingredients: The cut-up parts of the broiler chickens fed the test ingredient were presented in Table 5. There were no significant $(p>0.05)$ differences in the measurements of live weight, dressed weight, carcass percent, drumstick, wing, breast muscle and shank. Birds in T6 recorded the highest $(2.52 \mathrm{~kg})$ live weight and carcass weight $(2.02 \mathrm{~kg})$, followed by those in $T 5$.

Other parts (head, neck, back and thigh) were influenced $(p<0.05)$ by the experimental diets. Birds in T6 had the highest values $(2.95,4.60$ and12.53\%) in head, neck and thigh respectively. The highest weight (18.02\%) of back was recorded in T1. Birds in T4 had the highest values of 19.60 and $4.20 \%$ in breast muscle and shank respectively, while those in $\mathrm{T} 3$ recorded the lowest (14.65\%) in breast muscle, and those in T2 had the lowest $(3.56 \%)$ in shank. The visceral organs of the broiler chickens fed test ingredient were presented in Table 6. There were significant $(\mathrm{p}<0.05)$ differences in gizzard, pancreas, proven triculus and intestine, while other organs showed no significant $(\mathrm{p}>0.05)$ differences. The highest weight $(3.39 \%)$, for gizzard was recorded in birds fed treatment 4 (T4), while the lowest $(2.73 \%)$ was recorded in $\mathrm{T} 1$. Birds on $\mathrm{T} 5$ recorded the highest $(1.47 \%)$ in pancreas while, birds on T3 had the lowest $(0.32 \%)$. Birds on T3 had the highest $(0.71 \%)$ in proventriculus while, the lowest $(0.46 \%)$ was recorded in $\mathrm{T} 5$.

The highest weight $(10.47 \%)$ of intestine was recorded in treatment 6 (T6) while, the lowest $(7.12 \%)$ was recorded in T5. Treatment five (T5) recorded the highest weight $(0.19 \%)$ for spleen, treatment six (T6) recorded the highest weight $(2.05 \%)$ for liver, treatment five (T5) recorded the highest weight $(0.69 \%)$ for kidney, and treatment four (T4) had the highest weight $(0.56 \%)$ of heart. Results obtained for back were close to those reported by Muftau et al. (2015). Values obtained in this study for thigh fell within the report of Adua et al. (2012). Head and neck values in this study were lower than those reported by the authors.

The results of visceral organs show that there were no significant $(p>0.05)$ differences in all the parameters observed with the exception of the liver and intestine that showed significant $(p<0.05)$ differences. The liver and intestines were significantly influenced by the dietary treatments they tended to be longer in size. This observation is in agreement with the report of Hetland et al. (2003) that there were increase in lengths of gastro intestinal tracts of broilers and Japanese quails when high fibre diets were fed to them compared with the normal.

The above findings on carcass characteristics of broiler birds fed with the test ingredients correspond with the results of Isikwenu et al. (2010) who evaluated the effects of replacing groundnut cake with urea-treated and fermented brewer's dried grains fed broiler finishers and observed that all the carcass parameters evaluated were not significantly affected by the treatment.

\begin{tabular}{lllllllll}
\multicolumn{7}{c}{ Table 5: Cut-up parts of broiler chickens fed test ingredient } \\
\hline Cut-up part (\%) & T1 & T2 & T3 & T4 & T5 & T6 & SEM & $\boldsymbol{p}$ value \\
\hline Live weight $(\mathrm{kg})$ & 2.45 & 1.92 & 2.25 & 2.15 & 2.50 & 2.52 & 1.04 & 0.43 \\
Carcass weight $(\mathrm{kg})$ & 1.81 & 1.47 & 1.87 & 1.85 & 1.97 & 2.02 & 2.69 & 0.23 \\
Carcass \% & 73.88 & 77.60 & 83.11 & 86.05 & 78.80 & 80.16 & 2.69 & 0.19 \\
Head & $2.72^{\mathrm{ab}}$ & $2.48^{\mathrm{b}}$ & $2.80^{\mathrm{a}}$ & $2.39^{\mathrm{b}}$ & $2.80^{\mathrm{a}}$ & $2.95^{\mathrm{a}}$ & 6.22 & 0.04 \\
Neck & $4.54^{\mathrm{a}}$ & $4.17^{\mathrm{ab}}$ & $3.47^{\mathrm{b}}$ & $4.47^{\mathrm{ab}}$ & $3.77^{\mathrm{b}}$ & $4.60^{\mathrm{a}}$ & 0.79 & 0.14 \\
Back & $18.02^{\mathrm{a}}$ & $11.51^{\mathrm{c}}$ & $13.13^{\mathrm{b}}$ & $13.65^{\mathrm{b}}$ & $12.06^{\mathrm{bc}}$ & $12.26^{\mathrm{bc}}$ & 18.99 & 0.05 \\
Drumstick & 10.76 & 10.09 & 10.91 & 10.24 & 9.35 & 9.74 & 16.37 & 0.25 \\
Thigh & $12.40^{\mathrm{a}}$ & $10.85^{\mathrm{b}}$ & $12.35^{\mathrm{a}}$ & $11.70^{\mathrm{b}}$ & $10.99^{\mathrm{b}}$ & $12.53^{\mathrm{a}}$ & 20.29 & 0.10 \\
Wing & 9.82 & 8.06 & 9.05 & 9.32 & 8.76 & 8.45 & 14.90 & 0.11 \\
Breast muscle & 18.64 & 17.14 & 14.65 & 19.60 & 17.93 & 17.32 & 59.03 & 0.27 \\
Shank & 4.00 & 3.56 & 4.09 & 4.20 & 3.79 & 3.94 & 6.08 & 0.11 \\
\hline
\end{tabular}

Means with no superscripts on the same row does not differ significantly ( $p>0.05), a, b, c:$ means with different superscripts on the same row differ significantly $(p<0.05)$. SEM = Standard Error of Means, T1 = without GNS, T2 = untreated GNS, T3 = GNS soaked for three days, T4 $=$ GNS soaked for four days, T5 = GNS soaked for five days, T6 = GNS soaked for six days. 
Table 6: Visceral organ of broiler chickens fed test ingredients

\begin{tabular}{llllllll}
\hline Internal organs (\%) & T1 & T2 & T3 & T4 & T5 & T6 & SEM \\
\hline Liver & 1.92 & 1.78 & 1.74 & 2.04 & 1.98 & 2.05 & 3.92 \\
Kidney & 0.63 & 0.55 & 0.42 & 0.60 & 0.69 & 0.50 & 1.89 \\
Spleen & 0.12 & 0.11 & 0.12 & 0.15 & 0.19 & 0.14 & 0.35 \\
Gizzard & $2.73^{\mathrm{ab}}$ & $2.91^{\mathrm{ab}}$ & $3.00^{\mathrm{a}}$ & $3.39^{\mathrm{ab}}$ & $3.16^{\mathrm{b}}$ & $3.11^{\mathrm{ab}}$ & 6.00 \\
Pancreas & $0.36^{\mathrm{a}}$ & $0.46^{\mathrm{a}}$ & $0.32^{\mathrm{a}}$ & $0.46^{\mathrm{a}}$ & $1.47^{\mathrm{b}}$ & $0.39^{\mathrm{a}}$ & 4.85 \\
Proventriculus & $0.56^{\mathrm{a}}$ & $0.58^{\mathrm{b}}$ & $0.71^{\mathrm{a}}$ & $0.69^{\mathrm{a}}$ & $0.46^{\mathrm{c}}$ & $0.65^{\mathrm{a}}$ & 0.11 \\
Heart & 0.51 & 0.51 & 0.49 & 0.56 & 0.55 & 0.54 & 1.01 \\
Intestine & $7.53^{\mathrm{a}}$ & $8.65^{\mathrm{b}}$ & $9.63^{\mathrm{b}}$ & $8.66^{\mathrm{a}}$ & $7.12^{\mathrm{a}}$ & $10.47^{\mathrm{b}}$ & 16.45 \\
Abdominal fat & 0.93 & 1.04 & 0.92 & 1.08 & 1.43 & 0.90 & 0.10 \\
\hline
\end{tabular}

Means with no superscripts on the same row does not differ significantly ( $p>0.05), a, b$ : means with different superscripts on the same row differ significantly $(p<0.05)$. SEM = Standard Error of Means, $T 1=$ without GNS, $T 2=$ untreated GNS, T3 = GNS soaked for three days, T4 $=$ GNS soaked for four days, $T 5=$ GNS soaked for five days, $T 6=$ GNS soaked for six days

With the above, it was confirmed that the incorporation of alum-treated groundnut shell meal (ATGSM) in place of wheat offal in broiler diets does not cause any abnormal metabolic activities in their organs or systems and or toxicity, and therefore, safe for use in broiler production. This is in line with the report of Abdulrazak et al. (2014) who confirmed that the anti-nutritional contents of groundnut husk are below the lethal level and as such safe for consumption by animals. In this study, the organs weights obtained were in agreement with those reported by Fanimo et al. (2005) and Isikwenu et al. (2010) who confirmed that there were no gross morphological changes nor histopathological manifestation in the organs of birds fed diets compounded from various feed ingredients.

Conclusion: It can be concluded that feeding broiler chickens groundnut shell soaked above five days may significantly alter the haematological and serum biochemical variables. Therefore, treating groundnut shell with alum does not have adverse effect on haematology and serum biochemical indices of the birds, and can be used to replace wheat offal as source of fibre in broiler diets.

\section{REFERENCES}

Abdulrazak, S: Otie, D: Oniwapele, YA (2014). Proximate analysis and anti-nutritional factors of groundnut and melon husk. Online J. Anim. Feed Res., 4(2): $25-28$

Adua, MM: Alu, SE: Thani, RJ: Abubakar, HT: Matthew, UD (2012). Effect of different alkalitreated groundnut (Arachis hypogea) shell meal on blood parameters and meat yield of broiler finisher chickens. Scholarly J. Agric. Sci. 2(9): $224-230$

Duncan, DB (1955). Multiple ranges and Multiple FTest. Biometrics, 11:1-42
Ewuola, EO: Egbunike, GN (2008). Haematological and serum biochemical response of growing rabbit bucks fed different levels of dietary fumonisin. Afr. J.Biotech. 7: 4304-4309

Fanimo, AO: Bamgbose, AM: Abiola, MO: Adediran, M: Olaniyan, AI (2005). Carcass yield and blood parameters of broiler chickens feed melon husk diets supplemented with yeast. Proc. 1st Nigeria International Poultry Summit (NIPS), Feb. $20^{\text {th }}-$ $25^{\text {th }}, 2005$, Ota, Ogun State, Nigeria.

FAOSTAT, (1999). Food and Agricultural Organization of the United Nations.

Hetland, H: Svihus, B: Kroghahl, A (2003). Effects of oats hulls and wood shavings on digestion in broilers and layers fed diets based on whole or ground wheat. Brit. Poult. Sci., 44: 275282

Isikwenu, JO: Akpodiete, OJ: Omeje, SI: Okagbare, GO (2010). The effects of replacing groundnut cake with urea-treated and fermented brewers' dried grains on nutrient digestibility, retention and carcass characteristics of broiler finishers. Nig. $J$. Anim. Prod. 37(1): 1 -12

Jain, NC (1986). Schalm's Veterinary Haematology. 4th Edition, Philadelphia, Lea and Febiger

Kohn, RA: Allen, MS (1995). Enrichment of proteolytic activity relative tonitrogen in preparations from the rumen for vitro studies. Animal Feed Sci. Tech. 52: 1-14

Konuk, T (1981). Practical Physiology, Vet. J. Ankara University, 39(2): 27-34

Muftau, MA: Eneh, CV: Suleiman, AO: Ahmed, T: Umar, S (2014). Replacement value of fermented groundnut husk (FGH) for wheat offal meal in the diet of broiler chickens production of 39 Annual 
conference of Nigeria for Anim. Pro. Babcock Univ. IlishanRemo.Pp157-164

Muftau, MA:Eneh, CV: Suleiman, AO:Anlade, YDR:Ribah, MI (2015). Effect of dietary fermented groundnut husk for wheat offal on carcass and haematological characteristics of broiler chickens in Semi-Arid Area of Kebbi State, Nigeria. J. Agric. Vet. Sci.8 (4): 39-42

Muhammad, NO: Oloyede, OB (2009). Haematological parameters of broiler chicks fed Aspergillus niger - fermented Terminalia catappa seed meal-based diets. Global J. Biotechn .Biochem. 4(2): 179 - 183

Nworgu, FC: Adebowale, EA: Oredein, OA: Oni, A (1999). Prospects and economicsof broiler production using two plant protein sources. Trop. J. Animal Sci. 2: $159-166$

Odetola, OM: Ewuola, EO: Adu, AO (2012). Haematology, serum biochemistry and organ histopathology of rabbits fed graded levels of whole kenaf (Hibiscus cannabinus) seed meal. Inter. J. Agric. Res. 7(2): 86 - 92

Odetola, OM: Eruvbetine, D: Onagbesan, OM: Oduguwa, OO (2014). Haematology, serum biochemistry and relative organ weight of broiler fed raw and roasted kenaf seed meal as a replacement for full fat soybean meal. Nig. J. Animal Product. 41 (1): 135 - 146
Ojewola, GS: Erubuaja, AS: Okoye, FC: Lawal, AS: Akinmutimi, A (2003). Effect of inclusion of grasshopper meal on performance, nutrient utilization and organ of broiler chicken. $J$. Sustain. Agric. Environ. 5: $19-25$.

Peters, T: Biaamonte, GT: Doumas, BT (1982). Protein (Total protein) in serum urine and cerebrospinal fluid: albumin in serum. In: Selected method of clinical chemistry. Am. Ass. Clin. Chem., Washington DC.

Siulapwa, NJ: Simukoko, H (2005). Status of crop residues and Agro-industrial by-products as supplementary animal feeds in Zambia. A review http://bj,Hostingkun.nil/esap/ZAMB/ZAMB//Ge neral/cropszambia.php

Steel, RGD: Torrie, JH (1980). Principles and procedures of statistics. 2nd Ed. McGraw, Hill New York, U.S.A

Tijani, IA: Akanji, AM: Agbalaya, K: Onigemo, M (2015). Haematological and serum biochemical profiles of broiler chickens fed diets containing moringa leaf meals. Agro-Sci. J. Trop. Agric. Food. Environ. Extent. 14(3): 7-11

Usman, BA (2013). Vulnerability and adaptation capability of the rural poor farmers to climate change effect in Kwara State, Nigeria. Lapai Soc. Rev. 4(1): $142-162$

Wikivet, (2013). Haematology. Available at: en.wikipedia/wiki/haematology 